УДК 614(477)

DOI: https://doi.org/10.26642/jen-2020-4(94)-142-149

Л.Р. Криничко, к.мед.н., здобувач

Державний університет «Житомирська політехніка»

\title{
Оцінка сучасного стану здоров'я населення України
}

\begin{abstract}
У статті надано розгорнуту характеристику стану здоров'я населення Украӥни. Особливу увагу приділено демографічній ситуації в Украйні порівняно з провідними регіонами Всесвітньої організації охорони здоров'я. Охарактеризовано сучасний стан здоров'я населення світу за регіонами, а саме: в Африканському регіоні, в регіонах країн Америки, в регіоні Південно-Східної Азії, в Свропейському регіоні, в регіоні Східного Середземномор'я, в регіоні Західної частини Тихого океану. Оиінено стан материнської та дитячої смертності Світовим банком у регіонах Всесвітньої організачії охорони здоров'я. Здійснено очінювання вірусної захворюваності (нові випадки зараження ВІЛ, захворюваність на туберкульоз, захворюваність на малярію, поширеність поверхневого антигена гепатиту B (HBsAg) серед дітей віком до 5 років, зареєстрована кількість людей, які потребують лікування від ЗТБ) у регіонах Всесвітньоі організації охорони здоров'я. Охарактеризовано результати дослідження індексу здоров'я населення України. Проаналізовано світову статистику охорони здоров'я з метою визначення власне стану охорони здоров'я України та ї̈ найближчих сусідів: Молдови, Румунії, Угорщини, Словаччини, Польщі, Білорусі, Росії, Грузї. Проаналізовано тривалість життя населення цих краӥн. Здійснено оиінювання материнської та дитячої смертності в досліджуваних крайнах за статистичними даними Світового банку. Відображено економічні аспекти стану охорони здоров'я і запропоновано заходи для поліпшення ситуації, щзо склалася.

Ключові слова: стан здоров'я населення; регіони Всесвітньої організації охорони здоров'я; материнська та дитяча смертність; вірусна захворюваність; демографічна ситуація.
\end{abstract}

Актуальність теми. Стан здоров'я населення будь-якої країни є ключовим фактором соціальноекономічного розвитку країни, адже визначає стан людських ресурсів, а отже кадрового потенціалу для держави, інвесторів, роботодавців та інших учасників господарських відносин. Особливо важливим стан здоров'я населення $є$ під час формування та розробки державної політики в сфері охорони здоров'я. «Система охорони здоров'я регіону є одним з основоположних компонентів регіональної соціальноекономічної політики, сукупністю галузей, що характеризуються стійкими економічними, організаційними, технічними і технологічними зв'язками між суб'єктами системи, спрямованими на поліпшення відтворення населення. Система охорони здоров'я регіону є територіальним поєднанням суб'єктів галузей, об'єднаних для надання певних видів медичних послуг на основі встановлення економічних, соціальних, фінансових, правових взаємовідносин між собою і з органами державного управління. Удосконалення управління охороною здоров'я має бути направлене на забезпечення ефективного функціонування в регіонах системи охорони здоров'я і реалізації соціально-економічної політики регіонів». Усе зазначене актуалізує статистичний аналіз стану здоров'я населення України порівняно із світовими показниками.

Аналіз останніх досліджень та публікації, на які спирається автор. Питанням дослідження стану здоров'я населення присвячені наукові дослідження вітчизняних та зарубіжних вчених, таких як: Радиш Я.Ф., Бугайцов С.Г., Ярош Н.П., Рингач Н.О, Банчук М.В., Клименко О.В., Надюк 3.О., Курило Т.М., Рудий В.М., Мартинюк О.І., Лещенко В.В., Паращич I.М., Буравльов Л.О., Бедрик І.О., Ляховченко Л.А., Торбас О.М., Васюк Н.О., Корольчук О.Л., Висоцька Т.Є., Білоус І.В., Дудка В.В., Кузьмінський П.Й., Жилка К.І., Фірсова О.Д., Кризина Н.П., Мокрецов С.С., Коваленко Т.Ю., Білинська М.М., Джафарова Д.М., Фуртак I.I., Пітко Я.М., Дуб Н.Є., Фільц Ю.О., Штогрин О.П., Юристовська Н.Я., Шегедин Я.Ю., Шевчук В.В., Вовк С.М., Карлаш В.В., Устимчук О.В., Галацан О.В., Котляревський Ю.О., Кравченко Ж.Д., Лєрмонтова Ю.О. Напрямами оцінки здоров’я населення, що особливо актуальні на сьогодні, є: чисельність населення, очікувана тривалість життя при народжені, очікувана тривалість здорового життя, оцінка материнської та дитячої смертності, стан захворюваності населення на вірусні хвороби. Дослідження в зазначених напрямах характерне з позиції оцінки стану здоров’я в світі в розрізі регіонів та України і її найближчих сусідів.

Метою статті $\epsilon$ дослідження та оцінювання сучасного стану здоров'я населення України порівняно зі світовими показниками.

Викладення основного матеріалу. Всесвітньою організацією охорони здоров'я щорічно оприлюднюється звіт зі статистикою охорони здоров'я в країнах світу. Важливими показниками, що містяться в звіті, є чисельність населення та тривалість життя, що наведено в таблиці 1 [1].

(C) Л.Р. Криничко, 2020 
Стан здоров'я населення світу за регіонами

\begin{tabular}{|c|c|c|c|c|c|c|c|c|c|}
\hline \multirow[t]{2}{*}{ Регіон ВООЗ } & \multicolumn{3}{|c|}{$\begin{array}{c}\text { Загальна чисельність } \\
\text { населення (тис. осіб) } \\
\text { (2018 р.) }\end{array}$} & \multicolumn{3}{|c|}{$\begin{array}{c}\text { Очікувана } \\
\text { тривалість життя } \\
\text { при народженні } \\
\text { (2016 р.) } \\
\end{array}$} & \multicolumn{3}{|c|}{$\begin{array}{c}\text { Очікувана } \\
\text { тривалість } \\
\text { здорового життя } \\
\text { (2016 р.) } \\
\end{array}$} \\
\hline & Ч & Ж & $P$ & Ч & Ж & $\mathrm{P}$ & Ч & Ж & $\mathrm{P}$ \\
\hline $\begin{array}{l}\text { Афр } \\
\text { регіс }\end{array}$ & 530907 & 532833 & 1063740 & 59,6 & 62,7 & 61,2 & 52,6 & 54,9 & 53,8 \\
\hline $\begin{array}{l}\text { Регіо } \\
\text { Амер }\end{array}$ & 493940 & 507706 & 1001647 & 73,8 & 79,8 & 76,8 & 65,5 & 69,6 & 67,5 \\
\hline $\begin{array}{l}\text { Регіон Південно- } \\
\text { Східної Азії }\end{array}$ & 1016068 & 966171 & 1982238 & 67,9 & 71,3 & 69,5 & 59,5 & 61,3 & 60,4 \\
\hline $\begin{array}{l}\text { Свропейський } \\
\text { регіон }\end{array}$ & 449315 & 477596 & 26911 & 74,2 & 80,8 & 77,5 & 66,1 & 70,7 & 68,4 \\
\hline $\begin{array}{l}\text { Східного } \\
\text { емномор'я }\end{array}$ & 360913 & 338106 & 699019 & 67,7 & 70,7 & 69,1 & 59,1 & 60,4 & 59,7 \\
\hline $\begin{array}{l}\text { Регіон Західної } \\
\text { частини Тихого } \\
\text { океану }\end{array}$ & 978281 & 942859 & 1921140 & 75,0 & 78,9 & 76,9 & 67,7 & 70,0 & 68,9 \\
\hline Весь світ & 3829425 & 3765271 & 7594696 & 69,8 & 74,2 & 72,0 & 62,0 & 64,8 & 63,3 \\
\hline
\end{tabular}

Джерело: сформовано автором на основі $[3,4]$

Отже, наведені дані в таблиці 1 дають змогу розподілити загальну чисельність чоловічого та жіночого населення серед регіонів таким чином:

- в Африканському регіоні чоловіче населення становить близько 530907 тис. осіб, жінок при цьому - 532833 тис. осіб. Очікувана тривалість життя при народженні серед чоловіків становить понад 60 років $(59,6)$, а серед жінок - понад 63 роки $(62,7)$. Очікувана тривалість здорового життя складає у чоловіків більше ніж 53 роки $(52,6)$, у жінок - більше як 55 років $(54,9)$;

- в регіонах країн Америки чоловіче населення становить близько 493940 тис. осіб, жінок при цьому близько 507706 тис. осіб. Очікувана тривалість життя при народженні серед чоловіків становить понад 74 роки $(73,8)$, а серед жіночого складу населення - понад 80 років $(76,8)$. Очікувана тривалість здорового життя у чоловіків сягає більше як 66 роки $(65,5)$, у жінок - більше як 70 років $(69,6)$;

- у регіоні Південно-Східної Азії чоловіче населення $є$ найбільше серед зазначених країн та становить 1016068 тис. осіб, жіночий склад населення є також найвищий серед всіх країн та становить близько 966171 тис. осіб. Очікувана тривалість життя при народженні серед чоловіків становить понад 68 років $(67,9)$, а серед жіночого складу населення - понад 71 рік $(71,3)$. Очікувана тривалість здорового життя у чоловіків - більше як 60 років $(59,5)$, а у жінок - більше ніж 61 рік $(61,3)$;

- в Європейському регіоні чоловіче населення становить близько 449315 тис. осіб, кількість жінок при цьому - близько 477596 тис. осіб. Очікувана тривалість життя при народженні серед чоловіків становить понад 74 роки $(74,2)$, а серед жіночого складу населення - понад 78 років $(77,5)$. Очікувана тривалість здорового життя у чоловіків - більше ніж 66 років $(66,1)$, у жінок - більше як 71 рік $(70,7)$;

- у регіоні Східного Середземномор'я чоловічий склад населення становить близько 360913 тис. осіб, жінок при цьому - близько 338106 тис. осіб. Очікувана тривалість життя при народженні серед чоловіків становить понад 68 років $(67,7)$, а серед жіночого складу населення - понад 71 рік $(70,7)$. Очікувана тривалість здорового життя у чоловіків - більше як 59 років $(59,1)$, у жінок - більше як 60 років $(60,4)$;

- у регіоні Західної частини Тихого океану чоловіче населення становить близько 978281 тис. осіб, кількість жінок при цьому - близько 942859 тис. осіб. Очікувана тривалість життя при народженні серед чоловіків становить понад 75 років $(75,0)$, а серед жіночого складу населення - понад 79 років $(78,9)$. Очікувана тривалість здорового життя у чоловіків - більше як 68 років $(67,7)$, у жінок - більше як 69 років $(68,9)$.

Оцінка материнської та дитячої смертності Світовим банком у регіонах ВООЗ наведена в таблиці 2.

На основі зазначеного в таблиці 2 можна зробити такі висновки:

- в Африканському регіоні найвищий коефіцієнт материнської смертності серед решти регіонів та коефіцієнт смертності серед дітей віком до 5 років, що становлять 525 та 76 \% відповідно. Коефіцієнт неонатальної смертності склав в цьому регіоні $27 \%$; 
Оиінка смертності населення в регіонах ВОО3

\begin{tabular}{|c|c|c|c|c|}
\hline Країна & $\begin{array}{c}\text { Коефіціснт } \\
\text { материнської } \\
\text { смертності } \\
\text { (на } 100000 \\
\text { живонароджених) } \\
\text { (2017 р.) }\end{array}$ & $\begin{array}{c}\text { Частка пологової } \\
\text { допомоги } \\
\text { кваліфікованими } \\
\text { медичними } \\
\text { робітниками (\%) } \\
\text { (2010-2019 рр.) } \\
\end{array}$ & $\begin{array}{c}\text { Коефіціснт } \\
\text { смертності серед } \\
\text { дітей віком до } 5 \\
\text { років (на } 1000 \\
\text { живонароджених) } \\
(2018 \text { р.) } \\
\end{array}$ & $\begin{array}{c}\text { Коефіціснт } \\
\text { неонатальної } \\
\text { смертності } \\
\text { (на } 1000 \\
\text { живонароджених) } \\
\text { (2018 р.) }\end{array}$ \\
\hline $\begin{array}{l}\text { Африканський } \\
\text { регіон }\end{array}$ & 525 & - & 76 & 27 \\
\hline $\begin{array}{l}\text { Регіон країн } \\
\text { Америки }\end{array}$ & 57 & - & 14 & 7 \\
\hline $\begin{array}{l}\text { Регіон Південно- } \\
\text { Східної Азії }\end{array}$ & 152 & - & 34 & 20 \\
\hline $\begin{array}{l}\text { Свропейський } \\
\text { регіон }\end{array}$ & 13 & - & 9 & 5 \\
\hline $\begin{array}{l}\text { Регіон Східного } \\
\text { Середземномор'я }\end{array}$ & 164 & - & 47 & 26 \\
\hline $\begin{array}{l}\text { Регіон Західної } \\
\text { частини Тихого } \\
\text { океану }\end{array}$ & 41 & - & 12 & 6 \\
\hline Весь світ & 211 & 81 & 39 & 18 \\
\hline
\end{tabular}

Джерело: сформовано автором на основі [2, 3, 9]

- в регіоні країн Америки коефіцієнт материнської смертності та коефіцієнт смертності серед дітей віком до 5 років становлять 57 та 14 \% відповідно. Коефіцієнт неонатальної смертності склав у цьому регіоні 7 \%;

- у регіоні Південно-Східної Азії коефіцієнт материнської смертності та коефіцієнт смертності серед дітей віком до 5 років становлять 152 та 34 \% відповідно. Коефіцієнт неонатальної смертності в цьому регіоні становить $20 \%$;

- у регіоні Східного Середземномор'я коефіцієнт материнської смертності та коефіцієнт смертності серед дітей віком до 5 років становлять 164 та 47 \% відповідно. Коефіцієнт неонатальної смертності в цьому регіоні становить $26 \%$;

- у регіоні Західної частини Тихого океану коефіцієнт материнської смертності та коефіцієнт смертності серед дітей віком до 5 років становлять 152 та 34 \% відповідно. Коефіцієнт неонатальної смертності склав в цьому регіоні $20 \%$;

- в Свропейському регіоні коефіцієнт материнської смертності та коефіцієнт смертності серед дітей віком до 5 років є найнижчими серед інших регіонів та становлять 41 та 12 \% відповідно. Коефіцієнт неонатальної смертності становить $6 \%$.

Оцінку вірусної захворюваності в регіонах ВООЗ наведено в таблиці 3.

Таблиия 3

Захворюваність на вірусні хвороби в регіонах ВООЗ

\begin{tabular}{|c|c|c|c|c|c|}
\hline Країна & $\begin{array}{c}A^{1} \\
(2018 \text { p. })\end{array}$ & $\begin{array}{c}\overline{6}^{2} \\
(2018 \text { p.) }\end{array}$ & $\begin{array}{c}B^{3} \\
(2018 \text { p. })\end{array}$ & $\begin{array}{c}\Gamma^{4} \\
(2017 \text { p.) }\end{array}$ & $\begin{array}{c}Д^{5} \\
(2018 \text { p.) }\end{array}$ \\
\hline Африканський регіон & 1,07 & 231 & 229,3 & 2.34 & 592459240 \\
\hline Регіон країн Америки & 0,16 & 29 & 6,7 & 0,07 & 62906099 \\
\hline $\begin{array}{l}\text { Регіон } \\
\text { Південно-Східної Азії }\end{array}$ & 0,09 & 220 & 4,9 & 0,26 & 917512156 \\
\hline Свропейський регіон & 0,19 & 28 & 0,0 & 0,21 & 5857390 \\
\hline $\begin{array}{l}\text { Регіон Східного } \\
\text { Середземномор'я }\end{array}$ & 0,07 & 115 & 10,0 & 0,69 & 82215011 \\
\hline $\begin{array}{l}\text { Регіон Західної частини } \\
\text { Тихого Океану }\end{array}$ & 0,06 & 96 & 2,6 & 0,38 & 94381715 \\
\hline Весь світ & 0,24 & 132 & 57,4 & 0,80 & 1755331611 \\
\hline
\end{tabular}

Джерело: сформовано автором на основі [3, 4]

\footnotetext{
${ }^{1}$ нові випадки зараження ВІЛ (на 1000 неінфікованих)

2 захворюваність на туберкульоз (на 100000 людей населення)

3 Захворюваність на малярію (на 1000 схильних до ризику людей)

${ }^{4}$ поширеність поверхневого антигена гепатиту В (HBsAg) серед дітей віком до 5 років (\%)

5 зареєстрована кількість людей, які потребують лікування від ЗТБ
} 
Здійснивши оцінку захворюваності на вірусні хвороби в регіонах світу, можна зробити такі висновки:

- в Африканському регіоні зосереджено найвищі показники вірусних хвороб серед інших регіонів, адже нові випадки зараження ВІЛ становлять 1,07, захворюваність на туберкульоз складає 231 випадок, захворюваність на малярію - 229,3 випадків, поширеність поверхневого антигена гепатиту В (HBsAg) серед дітей віком до 5 років - 2,34 \%, зареєстрована кількість людей, які потребують лікування від ЗТБ, понад 592459240 тис. осіб;

- у регіоні країн Америки зафіксовано нові випадки зараження ВІЛ $(0,16)$, захворюваність на туберкульоз становить понад 29 випадків, захворюваність на малярію становить 6,7 випадків, поширеність поверхневого антигена гепатиту В (HBsAg) серед дітей віком до 5 років - 0,07 \%, зареєстрована кількість людей, які потребують лікування від ЗТБ, - понад 62906099 тис. осіб;

- у регіоні Південно-Східної Азії зареєстровано нові випадки зараження ВІЛ $(0,09)$, захворюваність на туберкульоз складає понад 220 випадків, захворюваність на малярію становить більше як 4,9 випадків, поширеність поверхневого антигена гепатиту B (HBsAg) серед дітей віком до 5 років - 0,26 \%, зареєстрована кількість людей, які потребують лікування від ЗТБ, - понад 917512156 тис. осіб;

- в Європейському регіоні виявлено нові випадки зараження ВІЛ (понад 0,19), захворюваність на туберкульоз становить понад 28 випадків, захворюваність на малярією не зафіксовано, поширеність поверхневого антигена гепатиту В (HBsAg) серед дітей віком до 5 років - 0,12\%, зареєстрована кількість людей, які потребують лікування від ЗТБ, - понад 9175857390 тис. осіб;

- у регіоні Східного Середземномор'я зафіксовано нові випадки зараження ВІЛ $(0,07)$, захворюваність на туберкульоз складає понад 115 випадків, захворюваність на малярію становить більше як 10 випадків, поширеність поверхневого антигена гепатиту В (HBsAg) серед дітей віком до 5 років 0,69 \%, зареєстрована кількість людей, які потребують лікування від ЗТБ, - понад 82215011 тис. осіб;

- у регіоні Західної частини Тихого океану спостерігаються нові випадки зараження ВІЛ $(0,06)$, захворюваність на туберкульоз складає понад 96 випадків, захворюваність на малярію становить більше як 2,6 випадків, поширеність поверхневого антигена гепатиту В (HBsAg) серед дітей віком до 5 років 0,38 \%, зареєстрована кількість людей, які потребують лікування від ЗТБ, - понад 94381715 тис. осіб.

Стан здоров'я населення в Україні. Питання здоров'я населення України $є$ важливим з позиції ії економічної стабільності, інвестиційної привабливості та налагодження соціального консенсусу [5]. У 2019 р. було проведено Загальнонаціональне дослідження індексу здоров'я населення України, в результаті чого було опитано 10000 респондентів. Основними результатами населення стали:

- «половина дорослих жителів України вважає своє здоров'я добрим (при цьому кожен десятий назвав його дуже добрим). Ще 37,9 \% вважають своє здоров'я посереднім, а 12,1 \% - поганим або дуже поганим;

- за результатами цьогорічного опитування показники охоплення населення основними профілактичними оглядами в цілому демонструють зростання. Спостерігається збільшення кількості звернень для проходження флюорографії ( 55,0 \% у 2018 р. до 57,3 \% у 2019 р.) та кардіограми (з 42,2 \% у 2018 р. до 44,4 \% у 2019 р.). Флюорографія залишається найпоширенішим видом профілактичного огляду; до нього за рік вдавалася більше ніж половина дорослого населення;

- більше половини опитаних жінок (52,0 \%) відвідували гінеколога 3 профілактичною метою впродовж останніх 12 місяців, 40,0 \% опитаних жінок здавали мазок на цитологічне дослідження і 22,2 \% робили мамографічне обстеження. За цими показниками результати у 2019 р. є дещо вищими, ніж ті, що були у 2017-2018 pр. Чоловіки звертаються до уролога з метою профілактики майже вдвічі рідше $(23,7$ \%), аніж жінки до гінеколога, і цей показник дещо зріс порівняно з 2018 р. (20,5%). Для обох статей характерне зменшення таких звернень з віком;

- понад 80 \% респондентів, які мають дітей віком до 18 років і володіють інформацією про стан свого здоров'я, позитивно ставляться до вакцинації. Окрім того, такі дослідження показують позитивну динаміку у ставленні населення до дитячої вакцинації: підтримували вакцинацію 70,9 \% у 2016 р., 73,4 \% у 2017 р., 74,5 \% у 2018 р. та 80,4 \% у 2019 р.;

- самолікуванням у разі виникнення хвороби займаються 45,4 \% опитаних дорослих $(31,7 \%$ вживають медикаменти, ще 13,7 \% лікуються за допомогою народних засобів). Для більш ніж третини населення (37,4 \%) звернення до медичного працівника є типовою поведінкою в разі хвороби: $27,0 \%$ звикли звертатися до сімейного / дільничного лікаря, 3,7 \% звертаються безпосередньо до вузького спеціаліста, 2,6 \% мають лікарів серед родичів, друзів чи знайомих, 2,9 \% викликають швидку допомогу, а $1,2 \%$ звертаються одразу до стаціонара;

- хоча сумарна частка прихильників самолікування залишається майже незмінною (близько 4547 \%), порівняно з результатами попередніх опитувань спостерігається поступове зростання частки тих, хто в разі захворювання звертається по допомогу до медичного працівника (з 29,0 \% у 2017 р. до 33,8 \% у 2018 р. та 37,4 \% у 2019 р.) переважно за рахунок почастішання візитів до сімейного / дільничного лікаря (18,6 \% y 2017 p., 23,1 \% y 2018 p. i $27,0 \%$ y 2019 p.)» [3]. 
Для визначення власне стану охорони здоров'я України та ії найближчих сусідів проаналізовано світову статистику охорони здоров'я, що формується та оприлюднюється Світовим банком [3, 6]. У межах дослідження визначено стан охорони здоров'я населення України та їі найближчих сусідів: Молдови, Румунії, Угорщини, Словаччини, Польщі, Білорусі, Росії, Грузії.

Важливим показником оцінки стану здоров’я населення є тривалість життя, що представлено в таблиці 4.

Аналіз тривалості життя населення Украӥни та ї̈ найближчих сусідів

Таблиия 4

\begin{tabular}{|c|c|c|c|c|c|c|c|c|c|}
\hline \multirow[t]{2}{*}{ Країна } & \multicolumn{3}{|c|}{$\begin{array}{c}\text { Загальна чисельність } \\
\text { населення (тис. осіб.) } \\
\text { (2018 р.) }\end{array}$} & \multicolumn{3}{|c|}{$\begin{array}{c}\text { Очікувана тривалість } \\
\text { життя при } \\
\text { народженні (2016 р.) }\end{array}$} & \multicolumn{3}{|c|}{$\begin{array}{c}\text { Очікувана } \\
\text { тривалість } \\
\text { здорового життя } \\
(2016 \text { р.) }\end{array}$} \\
\hline & Ч & Ж & 3 & $\mathrm{Y}$ & Ж & 3 & Ч & Ж & 3 \\
\hline Україна & 20491 & 23755 & 44246 & 67,6 & 77,1 & 72,5 & 60,3 & 67,6 & 64,0 \\
\hline Молдова & 1943 & 2108 & 4052 & 67,6 & 75,3 & 71,5 & 60,7 & 66,4 & 63,6 \\
\hline Румунія & 9491 & 10015 & 19506 & 71,6 & 79,0 & 75,2 & 63,7 & 69,7 & 66,6 \\
\hline Угорщина & 4618 & 5090 & 9708 & 72,3 & 79,4 & 76,0 & 64,1 & 69,5 & 66,8 \\
\hline Словаччина & 2654 & 2799 & 5453 & 73,8 & 80,9 & 77,4 & 65,3 & 71,2 & 68,3 \\
\hline Польща & 18380 & 19541 & 37922 & 73,8 & 81,6 & 77,7 & 65,4 & 71,7 & 68,5 \\
\hline Білорусь & 4400 & 5053 & 9453 & 68,8 & 79,2 & 74,2 & 61,4 & 69,3 & 65,5 \\
\hline Росія & 67531 & 78203 & 145734 & 6,4 & 77,2 & 72,0 & 59,1 & 67,5 & 63,5 \\
\hline Грузія & 1910 & 2093 & 4003 & 68,3 & 76,8 & 72,6 & 61,5 & 68,4 & 64,9 \\
\hline
\end{tabular}

Джерело: сформовано автором на основі $[3,6,10]$

На основі зазначеного вище можна зробити такі висновки:

- в Україні чисельність чоловічого населення серед інших представлених країн становить понад 20491 тис. осіб, жіночого населення - понад 23755 тис. осіб, очікувана тривалість життя при народженні чоловіків складає понад 68 років $(67,6)$, жінок - більше як 77 років $(77,1)$, очікувана тривалість здорового життя складає серед чоловіків понад 60 років $(60,3)$, серед жінок - понад 68 років $(67,6)$;

- у Молдові чисельність чоловічого населення серед інших представлених країн становить понад 1943 тис. осіб, жіночого - понад 2108 тис. осіб, очікувана тривалість життя при народженні чоловіків складає понад 68 років $(67,6)$, жінок - більше як 75 років $(75,3)$, очікувана тривалість здорового життя складає серед чоловіків понад 60 років $(60,7)$, серед жінок - понад 66 років $(66,4)$;

- у Румунії чисельність чоловічого складу населення серед інших представлених країн складає понад 9491 тис. осіб, жіночого - понад 10015 тис. осіб, очікувана тривалість життя при народженні чоловіків складає понад 71 рік $(71,6)$, жінок - більше як 79 років $(79,0)$, очікувана тривалість здорового життя становить серед чоловіків понад 63 роки $(63,7)$, серед жінок - понад 70 років $(69,7)$;

- в Угорщині чисельність чоловічого населення серед інших представлених країн сягає понад 4618 тис. осіб, жіночого - понад 5090 тис. осіб, очікувана тривалість життя при народженні чоловіків складає понад 72 роки $(72,3)$, жінок - більше як 81 рік $(80,9)$, очікувана тривалість здорового життя становить серед чоловіків понад 64 роки $(64,1)$, серед жінок- понад 70 років $(69,5)$;

- у Словаччині чисельність чоловічого населення серед інших представлених країн становить понад 2654 тис. осіб, жіночого - понад 2799 тис. осіб, очікувана тривалість життя при народженні чоловіків становить понад 73 роки $(73,8)$, жінок - більше як 79 років $(79,4)$, очікувана тривалість здорового життя складає серед чоловіків понад 65 років $(65,3)$, серед жінок - понад 71 років $(71,2)$;

- у Польщі чисельність чоловічого населення серед інших представлених країн складає понад 18380 тис. осіб, жіночого населення - понад 19541 тис. осіб, очікувана тривалість життя при народженні чоловіків складає понад 73 роки $(73,8)$, жінок - більше як 82 роки $(81,6)$, очікувана тривалість здорового життя становить серед чоловіків понад 65 років $(65,4)$, серед жінок - понад 71 рік $(71,7)$;

- у Білорусії чисельність чоловічого населення серед інших представлених країн становить понад 4400 тис. осіб, жіночого - понад 5053 тис. осіб, очікувана тривалість життя при народженні чоловіків складає понад 69 років $(68,8)$, жінок - більше як 79 років $(79,2)$, очікувана тривалість здорового життя становить серед чоловіків понад 61 рік $(61,4)$, серед жінок - понад 69 років $(69,3)$;

- у Росії найбільша чисельність чоловічого населення серед інших представлених країн, що становить понад 67531 тис. осіб та жіночого складу - понад 78203 тис. осіб, очікувана тривалість життя при народженні чоловіків складає понад 66 років $(66,4)$, жінок - більше як 77 років $(77,2)$, очікувана тривалість здорового життя становить серед чоловіків понад 59 років $(59,1)$, серед жінок - понад 68 років $(67,5)$; 
- у Грузії чисельність чоловічого населення серед інших представлених країн становить понад 1910 тис. осіб, жіночого - понад 2093 тис. осіб, очікувана тривалість життя при народженні чоловіків складає понад 69 років $(68,3)$, жінок - більше як 77 років $(76,8)$, очікувана тривалість здорового життя складає серед чоловіків понад 61 рік $(61,5)$, серед жінок - понад 68 років $(68,4)$.

Оцінка материнської та дитячої смертності Світовим банком у досліджуваних країнах зазначена в таблиці 5.

Очінка смертності населення в Україні та ї̈ найближчих сусідів

Таблиия 5

\begin{tabular}{|c|c|c|c|c|}
\hline Країна & $\begin{array}{c}\text { Коефіціснт } \\
\text { материнської } \\
\text { смертності } \\
\text { (на } 100000 \\
\text { живонароджених) } \\
\text { (2017 р.) }\end{array}$ & $\begin{array}{c}\text { Частка пологової } \\
\text { допомоги } \\
\text { кваліфікованими } \\
\text { медичними } \\
\text { робітниками, \% } \\
\text { (2010-2019 рр.) }\end{array}$ & $\begin{array}{c}\text { Коефіціснт } \\
\text { смертності серед } \\
\text { дітей віком до } \\
5 \text { років (на } 1000 \\
\text { живонароджених) } \\
\text { (2018 р.) }\end{array}$ & $\begin{array}{c}\text { Коефіціснт } \\
\text { неонатальної } \\
\text { смертності } \\
\text { (на } 1000 \\
\text { живонароджених) } \\
\text { (2018 р.) }\end{array}$ \\
\hline Україна & 19 & 100 & 9 & 5 \\
\hline Молдова & 19 & 100 & 16 & 12 \\
\hline Румунія & 19 & 97 & 7 & 3 \\
\hline Угорщина & 12 & 100 & 4 & 2 \\
\hline Словаччина & 5 & 98 & 6 & 3 \\
\hline Польща & 2 & 100 & 4 & 3 \\
\hline Білорусь & 2 & 100 & 3 & 1 \\
\hline Росія & 17 & 100 & 7 & 3 \\
\hline Грузія & 25 & 99 & 10 & 6 \\
\hline
\end{tabular}

На основі вказаного вище можна зробити такі висновки:

- в Україні коефіцієнт материнської смертності становить понад 19 \%, коефіцієнт смертності серед дітей віком до 5 років складає понад $9 \%$ та коефіцієнт неонатальної смертності - більше як $5 \%$;

- в Молдові коефіцієнт материнської смертності становить понад 19 \%, коефіцієнт смертності серед дітей віком до 5 років складає понад $16 \%$ та коефіцієнт неонатальної смертності - більше ніж $12 \%$;

- в Румунії коефіцієнт материнської смертності становить понад 19 \%, коефіцієнт смертності серед дітей віком до 5 років складає понад 7 \% та коефіцієнт неонатальної смертності - більше як $3 \%$;

- в Угорщині коефіцієнт материнської смертності становить понад 12 \%, коефіцієнт смертності серед дітей віком до 5 років складає понад 4 \% та коефіцієнт неонатальної смертності - більше як $2 \%$;

- в Словаччині коефіцієнт материнської смертності становить понад 5 \%, коефіцієнт смертності серед дітей віком до 5 років складає понад 6 \% та коефіцієнт неонатальної смертності - більше як $3 \%$;

- в Польщі коефіцієнт материнської смертності становить понад 2 \%, коефіцієнт смертності серед дітей віком до 5 років складає понад 4 \% та коефіцієнт неонатальної смертності - більше як $3 \%$;

- в Білорусії зафіксовано найменші показники смертності населення, адже коефіцієнт материнської смертності становить $2 \%$, коефіцієнт смертності серед дітей віком до 5 років складає понад $3 \%$ та коефіцієнт неонатальної смертності - лише $1 \%$;

- в Росії коефіцієнт материнської смертності становить понад 17 \%, коефіцієнт смертності серед дітей віком до 5 років складає понад 7 \% та коефіцієнт неонатальної смертності - більше як 3 \%;

- в Грузії спостерігаються найбільші показники смертності населення, адже коефіцієнт материнської смертності становить понад $25 \%$, коефіцієнт смертності серед дітей віком до 5 років складає понад $10 \%$ та коефіцієнт неонатальної смертності - понад $6 \%$.

Оцінку вірусної захворюваності наведено в таблиці 6 та зазначено такі показники:

- в Україні, Грузії та Молдові спостерігається найбільша захворюваність на туберкульоз та виявлено найбільшу кількість нових випадків ВІЛ серед інших країн, адже в Україні та Грузії захворюваність на туберкульоз становить понад 80 випадків, в Молдові - понад 86 випадків, а кількість нових випадків зараження ВІЛ зареєстровано в Україні понад 0,28, в Молдові - понад 0,25, в Грузії - понад 0,18 ; поширеність поверхневого антигена гепатиту В (HBsAg) серед дітей віком до 5 років в Україні складає понад $0,46 \%$, в Молдові - понад $0,65 \%$, в Грузії - понад 0,26 \%;

- в Румунії зафіксовано нові випадки зараження ВІЛ, які становлять понад 0,04, захворюваність на туберкульоз складає більше як 68 випадків, поширеність поверхневого антигена гепатиту B (HBsAg) серед дітей віком до 5 років становить понад $0,65 \%$; 
Показник захворюваності на вірусні хвороби в Україні та ї̈ найближчих сусідів

\begin{tabular}{|c|c|c|c|c|c|}
\hline Країна & $\mathbf{A}^{6}$ & $\mathbf{6}^{7}$ & $\mathbf{B}^{8}$ & $\boldsymbol{\Gamma}^{9}$ & $\boldsymbol{Д}^{10}$ \\
\hline Україна & 0,28 & 80 & - & 0,46 & 0 \\
\hline Молдова & 0,25 & 86 & - & 0,65 & 0 \\
\hline Румунія & 0,04 & 68 & - & 0,65 & 0 \\
\hline Угорщина & 0,02 & 6,4 & - & 0,44 & 0 \\
\hline Словаччина & 0,02 & 5,8 & - & 0,56 & 6 \\
\hline Польща & 0,04 & 16 & - & 0,04 & 36 \\
\hline Білорусь & 0,22 & 31 & - & 0,20 & 0 \\
\hline Росія & - & 54 & - & 0,88 & 3 \\
\hline Грузія & 0,18 & 80 & - & 0,26 & 412310 \\
\hline
\end{tabular}

Джерело: сформовано автором на основі $[3,6,10]$

- в Угорщині зосереджено понад 0,02 нових випадки зараження ВІЛ, захворюваність на туберкульоз становить понад 6,4 випадків, поширеність поверхневого антигена гепатиту В (HBs Ag) серед дітей віком до 5 років - більше як $0,44 \%$;

- в Словаччині виявлено понад 0,02 нових випадки зараження ВІЛ, захворюваність на туберкульоз становить понад 5,8 випадків, поширеність поверхневого антигена гепатиту В (HBs Ag) серед дітей віком до 5 років - більше як $0,56 \%$;

- в Польщі спостерігається нових випадків зараження ВІЛ понад 0,04, захворюваність на туберкульоз становить понад 16 випадків, поширеність поверхневого антигена гепатиту B (HBsAg) серед дітей віком до 5 років - більше як $0,04 \%$;

- в Білорусії зафіксовано 0,22 нових випадків зараження ВІЛ, захворюваність на туберкульоз становить понад 31 випадок, поширеність поверхневого антигена гепатиту В (HBsAg) серед дітей віком до 5 років - більше як $0,20 \%$;

- в Росії не виявлено нових випадків зараження ВІЛ, захворюваність на туберкульоз становить понад 54 випадки, поширеність поверхневого антигена гепатиту В (HBsAg) серед дітей віком до 5 років більше як $0,88 \%$.

Висновки та перспективи подальших досліджень. Проведений статистичний аналіз дозволив виявити найбільш критичні точки щодо розвитку системи охорони здоров'я в Україні. Зокрема, в останні десятиліття спостерігається падіння чисельності населення України, що є негативною тенденцією, яка характеризує низький рівень медичної допомоги в країні. Оцінено материнську та дитячу смертність у регіонах Всесвітньої організації охорони здоров'я, і варто зауважити, що в Свропейському регіоні коефіцієнт материнської смертності та коефіцієнт смертності серед дітей віком до 5 років $є$ найнижчий серед інших аналізованих регіонів та становить $41 \%$ та 12 \% відповідно, а коефіцієнт неонатальної смертності в цьому регіоні теж є найнижчим та становить $6 \%$. Здійснивши оцінку захворюваності на вірусні хвороби в регіонах світу, слід зазначити, що в регіоні країн Америки та в Свропейському регіоні зафіксовано найменшу кількість нових випадків зараження ВІЛ 0,16 та 0,19 осіб відповідно, захворюваність на туберкульоз складає понад 29 та 28 випадків, захворюваність на малярію становить 6 та 7 випадків. Аналіз тривалості життя населення України та ії найближчих сусідів свідчить, що очікувана тривалість життя при народженні чоловіків в Україні складає понад 68 років $(67,6)$, жінок більше як 77 років $(77,1)$, очікувана тривалість здорового життя українців складає серед чоловіків понад 60 років $(60,3)$, серед жінок - понад 68 років $(67,6)$.

Отже, стан охорони здоров'я населення відіграє важливу роль у створенні підгрунтя для здоров'я населення, профілактики та лікування поширених захворювань, пропаганди здорового способу життя, зміцнення здоров'я боєздатної нації та забезпечення безпеки держави. Рівень здоров'я населення України, його збереження і поліпшення є медико-соціальною проблемою, яка потребує оптимального вирішення залежно від тих чи інших умов сьогодення, при зміні яких виникає необхідність вдосконалення організації та управління системою заходів з досягнення мети.

\footnotetext{
${ }^{6}$ нові випадки зараження ВІЛ (на 1000 неінфікованих)

7 захворюваність на туберкульоз (на 100000 людей населення)

8 захворюваність на малярію (на 1000 схильних до ризику людей)

${ }^{9}$ поширеність поверхневого антигена гепатиту B (HBsAg) серед дітей віком до 5 років (\%)

10 зареєстрована кількість людей, які потребують лікування від ЗТБ
} 


\section{Список використаної літератури:}

1. Богатирьова Р.В. Детермінанти здоров’я та національна безпека / Р.В. Богатирьова. - К. : ВД «Авіценна», 2011. -448 c.

2. Статівка Н.В. Демографічна складова економічної безпеки України / Н.В. Статівка, А.А. Смаглюк // Державне будівництво. - 2010. - № 2 [Електронний ресурс]. - Режим доступу : http://www.kbuapa.kharkov.ua/e-book/db/2010-2/doc/2/12.pdf.

3. Мировая статистика здравоохранения: мониторинг показателей здоровья в отношении ЦУР, целей в области устойчивого развития. - Женева : Всемирная организация здравоохранения, 2020 [Электронный pecypc]. - Режим доступа : https://creativecommons.org/licenses/by-nc-sa/3.0/igo.

4. Індекс здоров'я. Україна - 2019: Результати загальнонаціонального дослідження. - Київ, 2020.

5. Чепелевська Л.А. Проблеми медико-демографічної ситуації та заходи з ії покращення / Л.А. Чепелевська, О.М. Дзюба // Вісник соціальної гігієни та організації охорони здоров’я України. - 2017. - № 1 (71). - С. 19-23.

6. Чепелевська Л.А. Тенденції медико-демографічних показників України у ХХІ столітті / Л.А. Чепелевська // Україна. Здоров’я нації. - 2018. - № 1. - С. 48-53.

7. Слабкий Г.О. Динаміка перинатальної і неонатальної смертності в період реформування системи охорони здоров’я України / Г.О. Слабкий, О.О. Дудіна, Ю.Ю. Габореиь // Україна. Здоров’я нації. - 2018. - № 2. С. $63-69$.

8. Дудник С.В. Економічні збитки держави внаслідок малюкової смертності / С.В. Дудник // Економіка і право охорони здоров'я. -2017 . - № 1. - С. 5-10.

9. Дудіна О.О. Медичні аспекти народжуваності (стан дітородної діяльності) / О.О. Дудіна, Ю.Ю. Габорещь // Україна. Здоров’я нації. - 2017. - № 4 (1). - С. 39-46.

10. Показники здоров'я населення та використання ресурсів охорони здоров'я в Україні за 2016-2017 роки / уклад.: В.М. Заболотько, Н.Г. Кравчук, І.С. Стешенко та ін. ; Центр мед. статистики МОЗ України. - Київ : Поліум, 2018. - $327 \mathrm{c}$.

\section{References:}

1. Bogatyr'ova, R.V. (2011), Determinanty zdorov'ja ta nacional'na bezpeka, VD «Avicenna», K., 448 p.

2. Stativka, N.V. and Smagljuk, A.A. (2010), «Demografichna skladova ekonomichnoi' bezpeky Ukrai'ny», Derzhavne budivnyctvo, No. 2, [Online], available at: http://www.kbuapa.kharkov.ua/e-book/db/20102/doc/2/12.pdf

3. Mirovaya statistika zdravookhraneniya: monitoring pokazatelei zdorov'ya $v$ otnoshenii TsUR, tselei $v$ oblasti ustoichivogo razvitiya (2020), Vsemirnaya organizatsiya zdravookhraneniya, Zheneva, [Online], available at: https://creativecommons.org/licenses/by-nc-sa/3.0/igo

4. Indeks zdorov'ja. Ukrai'na - 2019: Rezul'taty zagal'nonacional'nogo doslidzhennja (2020), Kyi'v.

5. Chepelevs'ka, L.A. and Dzjuba, O.M. (2017), «Problemy medyko-demografichnoi' sytuacii' ta zahody z i'i' pokrashhennja», Visnyk social'noi' gigijeny ta organizacii' ohorony zdorov'ja Ukrai'ny, No. 1 (71), pp. 19-23.

6. Chepelevs'ka, L.A. (2018), «Tendencii' medyko-demografichnyh pokaznykiv Ukrai'ny u XXI stolitti», Ukrai'na. Zdorov'ja nacii', No. 1, pp. 48-53.

7. Slabkyj, G.O., Dudina, O.O. and Gaborec', Ju.Ju. (2018), «Dynamika perynatal'noi' i neonatal'noi' smertnosti v period reformuvannja systemy ohorony zdorov'ja Ukrai'ny», Ukrai'na. Zdorov'ja nacii', No. 2, pp. 63-69.

8. Dudnyk, S.V. (2017), «Ekonomichni zbytky derzhavy vnaslidok maljukovoi' smertnosti», Ekonomika i pravo ohorony zdorov'ja, No. 1, pp. 5-10.

9. Dudina, O.O. and Gaborec', Ju.Ju. (2017), «Medychni aspekty narodzhuvanosti (stan ditorodnoi' dijal'nosti)», Ukrai'na. Zdorov'ja nacii', No. 4 (1), pp. 39-46.

10. Zabolot'ko, V.M., Kravchuk, N.G., Steshenko, I.Je. et al. (ed.) (2018), Pokaznyky zdorov'ja naselennja ta vykorystannja resursiv ohorony zdorov'ja v Ukrai'ni za 2016-2017 roky, Centr med. statystyky MOZ Ukrai'ny, Polium, Kyi'v, 327 p.

Криничко Лілія Романівна - кандидат медичних наук, здобувач кафедри економічної безпеки, публічного управління та адміністрування Державного університету «Житомирська політехніка».

Наукові інтереси:

- реформування системи охорони здоров'я;

- державне управління системою охорони здоров'я. 